\title{
Entactin Stimulates Neutrophil Adhesion and Chemotaxis through Interactions between Its Arg-Gly-Asp (RGD) Domain and the Leukocyte Response Integrin
}

Robert M. Senior, * Hattie D. Gresham, * Gail L. Griffin, * Eric J. Brown, ${ }^{3}$ and Albert E. Chung"

${ }^{*}$ Respiratory and Critical Care Division, Department of Medicine, Jewish Hospital at Washington University Medical Center, St. Louis, Missouri 63110; ${ }^{\ddagger}$ Department of Pharmacology, University of Missouri at Columbia, Columbia, Missouri $65212 ;{ }^{\S}$ Division of Infectious Diseases, Department of Medicine, Departments of Cell Biology and Molecular Microbiology, Washington University, St. Louis, Missouri 63110; and "Department of Biological Sciences, University of Pittsburgh, Pittsburgh, Pennsylvania 15260

\section{Abstract}

Entactin is an integral component of basement membranes that plays a major role in basement membrane assembly through its ability to bind avidly to both laminin and type IV collagen. Because neutrophil (PMN) interactions with entactin have not been examined, we investigated the ability of natural and recombinant entactin to mediate PMN adhesion and chemotaxis. With both forms of entactin, we observed that entactin-coated surfaces promoted PMN adhesion and that entactin stimulated PMN chemotaxis. The increase in adhesion to entactin over control was two to threefold whereas the chemotactic response to $15 \mathrm{ng} / \mathrm{ml}\left(1 \times 10^{-10} \mathrm{M}\right)$ entactin was equivalent to the chemotactic response elicited with $1 \times 10^{-8} \mathrm{M}$ formyl-methionyl-leucyl-phenylalanine ( $\mathrm{f}$ MLP). HL-60 cells, after differentiation with dimethylsulfoxide, also demonstrated adhesion and chemotaxis to entactin. A synthetic peptide of the Arg-GlyAsp (RGD) domain in entactin, SIGFRGDGQTC (S-RGD), mediated PMN adhesion and chemotaxis, and preexposure of PMN to S-RGD blocked PMN adhesion and chemotaxis induced by entactin without diminishing the adhesive and chemotactic activities of $f$ MLP. In contrast, preexposure to peptides SIGFRGEGQTCA or SIGFKGDGQTCA had no effect. The findings with synthetic peptides were confirmed with a recombinant entactin mutant in which aspartic acid at residue 674 was replaced with glutamic acid, thus converting the RGD sequence of entactin to RGE. RGE-entactin was neither adhesive nor chemotactic for neutrophils. Monoclonal antibodies to the leukocyte response integrin (LRI) and the integrin-associated protein blocked entactin-mediated adhesion and chemotaxis whereas monoclonal antibodies to $\beta_{1}$ and $\beta_{2}$ integrins had no effect and PMN from an individual with leukocyte-adhesion deficiency adhered normally to entactin-coated surfaces. These data demonstrate that entactin mediates biologically and pathologically important functions of PMN through its RGD domain and that LRI, which has been shown previously to mediate RGD-stimulated phagocytosis, is also capable of mediating RGD-stimulated PMN adhesion and chemotaxis. (J. Clin. Invest. 1992.90:2251-2257.) Key words: basement membrane • inflammation • phagocytosis $\cdot$ HL-60 cells $\bullet$ site-directed mutagenesis

Address correspondence to Robert M. Senior, M. D., Jewish Hospital, 216 South Kingshighway Boulevard, St. Louis, MO 63110.

Received for publication 24 January 1992 and in revised form 26 May 1992.

J. Clin. Invest.

(c) The American Society for Clinical Investigation, Inc. $0021-9738 / 92 / 12 / 2251 / 07 \quad \$ 2.00$

Volume 90, December 1992, 2251-2257

\section{Introduction}

Acute inflammation is a complex response to local injury or infection (1). The hallmark of acute inflammation is the rapid emigration of (PMNs) from the vasculature into the site of injury or infection. An early, critical event in the acute inflammatory response is adhesion of PMN to the endothelium at the site of inflammation. PMN-endothelial cell adhesion is mediated by specific plasma membrane molecules on both cell types and is markedly regulated by numerous protein and lipid factors specifically synthesized at sites of inflammation or infection $(2,3)$. Because PMN-endothelial adhesion is necessary for the development of the host response, it has been the focus of intense investigation $(4,5)$. Inhibitors of PMN adhesion to endothelium have shown a marked protective effect in experimentally induced acute inflammation in vivo (6).

Less well defined have been the events subsequent to PMN-endothelial cell adhesion, involving diapedesis of PMN through the endothelial basement membrane into the underlying tissue. Recent studies suggest that emigrating PMN cause focal disruption of the basement membrane, however, the mechanisms for producing the defects are obscure since inhibitors of neutrophil proteinases and endoglycosidases are without effect (7).

Previous investigations have shown that at least two components of the basement membrane, laminin and type IV collagen, stimulate PMN chemotaxis, adhesion, and enhanced phagocytosis of $\operatorname{IgG}$ opsonized targets (8-14). Entactin is a more recently described basement membrane protein that binds to both type IV collagen and laminin and to cells (1517). Interactions between PMN and entactin have not been investigated. In the present report we demonstrate that entactin promotes PMN adhesion and chemotaxis and that both of these effects of entactin involve interactions between the ArgGly-Asp (RGD) ${ }^{1}$ sequence in entactin with the leukocyte response integrin (LRI), a recently described integrin (10). Monoclonal antibodies to the $\beta_{1}$ and $\beta_{2}$ integrins do not diminish the adhesive or chemotactic activity of entactin, and PMN that lack $\beta_{2}$ integrin expression adhere normally to entactincoated surfaces. These findings suggest that interactions between PMN and entactin could be an important event in PMN passage through endothelial basement membranes.

1. Abbreviations used in this paper: E, erythrocytes; fMLP, formylmethionyl-leucyl-phenylalanine; hpg, high power grid; IAP, integrinassociated protein; LAD, leukocyte adhesion deficiency; LRI, leukocyte response integrin; RGD, Arg-Gly-Asp; RGE-entactin, mutant recombinant entactin in which aspartic acid at residue 674 has been replaced with glutamic acid; S-RGD, SIGFRGDGQTC; S-RGE, SIGFRGEGQTCA; S-KGD, SIGFKGDGQTCA; Sf9 cells, Spodoptera frugiperda cells. 


\section{Methods}

Cells. PMN were isolated from peripheral venous blood of healthy adult volunteers and one individual with leukocyte-adhesion deficiency (LAD) using Ficoll-Hypaque. HL-60 cells were purchased from the American Type Tissue Collection (Rockville, MD) and maintained in RPMI supplemented with $10 \%$ fetal bovine serum (Tissue Culture Support Center, Washington University Medical Center, St. Louis, MO). To promote neutrophilic differentiation, HL-60 cells were incubated with $1.3 \%$ ( $\mathrm{vol} / \mathrm{vol}$ ) dimethylsulfoxide for 48 to $72 \mathrm{hr}$ $(18,19)$.

Entactin, SIGFRGDGQTC (S-RGD) and related peptides, and formyl-methionyl-leucyl-phenylalanine ( $f M L P)$. Entactin was purified from M1536-B3 extracellular matrix preparations (20). Recombinant entactin was obtained from the baculovirus system previously described (21). S-RGD was synthesized by Multiple Peptide Sys. (San Diego, CA). SIGFRGDGQTCA (S-RGD'), SIGFRGEGQTCA (SRGE), and SIGFKGDGQTCA (S-KGD) were synthesized using 9fluorenylmethyloxycarbonyl chemistry and the Ramps system (Dupont Co., Wilmington, DE) (22). Peptides were purified by reverse phase HPLC after synthesis. Both S-RGD and S-RGD' were used in all experiments involving S-RGE or S-KGD and their effects were indistinguishable. fMLP was purchased from Sigma Chemical Co. (St. Louis, MO).

$R G E$-entactin mutant. The single RGD sequence of entactin is located at amino acid residues 672-674 (23). An RGE-entactin mutant (RGE-entactin) was made in which the aspartic acid at residue 674 was replaced with glutamic acid $(D \rightarrow E)$. The mutagenic oligonucleotide was 5' AGT CGT CCC CTC TCC TCG GAA 3'. Site-directed mutagenesis was performed as described (24-26). The bluescript cDNA clone E663 containing nucleotides 1,661-3,520 of the entactin sequence and which coded for the RGD peptide (23) was transformed into a dut ${ }^{-}$ung $^{-}$Escherichia coli strain CJ236 (a gift from Dr. Duncan Groebe and also available from Bio-Rad Laboratories, Richmond, CA). The transformed CJ236 bacteria were grown in the presence of an excess amount of uracil to generate uracil containing single-stranded DNA template. The exponentially growing bacteria were infected with the helper phage M13K07 (Bio-Rad Laboratories) at MOI 20 to package the single-stranded phagemid DNA. After $1 \mathrm{~h}$ of infection, kanamycin was added to the culture medium and incubation continued overnight. The phage particles were collected by polyethylene glycol/ $\mathrm{NaCl}$ precipitation (27). To check the level of uracil incorporation into the single-stranded DNA, the titer of the phage preparation was determined on both CJ236 (dut ${ }^{-}$ung $^{-}$) and JM109 (dut ${ }^{+}$ung $^{+}$) by following previously described procedures (26). A plaque ratio $\geq 10^{5}-10^{6}$ indicates that enough uracil has been incorporated into the DNA templates.

The mutagenic oligomers were first phosphorylated using polynucleotide kinase (Bethesda Research Laboratories, Gaithersburg, MD) and then annealed to the single-stranded templates over a period of 30 min. For the second-strand synthesis, the oligomer annealed to the template was extended with the Klenow fragment of DNA polymerase (Bethesda Research Laboratories) and the ends were ligated using T4 DNA ligase (Bethesda Research Laboratories). The resultant heteroduplex was subsequently transformed into $\mathrm{JM} 109$ (dut ${ }^{+}$ung $^{+}$), and the mutants were screened by DNA sequence analysis using the dideoxy chain-termination method.

The mutant forms of E663 were sequentially restricted with SphI and HindIII to yield a $3.8-\mathrm{kbp}$ fragment that included the bluescript vector sequences and a segment derived from entactin which contained the mutant sequence. This fragment was isolated by electrophoresis on an agarose gel. An SphI-SacI fragment was removed from a previously described full-length cDNA clone of entactin in bluescript (20) and ligated to the 3.8-kbp mutant fragment to generate a new vector. An Ncol-Ncol fragment of this new vector, which contained the mutated sequences, was isolated. This fragment was then used to replace the corresponding fragment in the recombinant baculovirus transfer vector pAcEn (20), thereby generating the mutant entactin sequence in the transfer vector.
$2.5 \times 10^{6}$ Spodoptera frugiperda cells ( $\mathrm{S} f$ ) $(20)$ were cotransfected with $12 \mu \mathrm{g}$ of a 1:5 mixture of baculovirus DNA and the mutant pAcEn. The procedures were as described by Tsao et al. (20), except that for the transfection Lipofectin (Bethesda Research Laboratories) was used instead of calcium phosphate (28). After $7 \mathrm{~d}$ of culture, the culture media were collected and screened for the recombinant virus ( 20 , 28). Briefly, Sf9 cells were seeded in 96-well microtiter plates and serially diluted virus was added to the wells. After $7 \mathrm{~d}$ of culture, the media were saved and cells lysed and blotted onto nitrocellulose membrane using a dot blot apparatus (28). The blots were then hybridized to a ${ }^{32} \mathrm{P}$-cDNA entactin probe. The media from positive clones were diluted and used for the next round of screening.

Sf9 monolayers were infected with culture medium containing recombinant virus and grown for $3 \mathrm{~d}$. Cells were then harvested and rinsed briefly in PBS containing protease inhibitors. Cell pellets were resuspended in $0.25 \%$ Chaps in PBS, vortexed, and incubated on ice for $1 \mathrm{~h}$. The mixture was centrifuged and the resulting pellet resuspended

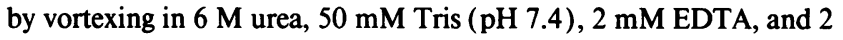
$\mathrm{mM}$ DTT plus protease inhibitors. Entactin was extracted from the mixture by stirring overnight at $4^{\circ} \mathrm{C}$. The insoluble materials were removed by centrifugation and the supernatant solution was collected and further purified by gel electrophoresis (20). Silver stain of RGEentactin subjected to PAGE revealed a single band at $150 \mathrm{kD}$.

Antibodies. Monoclonal antibodies $\mathrm{B} 6 \mathrm{H} 12$, directed against the integrin-associated protein (IAP), and 7G2, directed against $\beta_{3}$ integrins were prepared as previously described (10). A1A5 and 4B4, anti- $\beta_{1}$ beta-chain integrin monoclonal antibodies, were obtained from Dr. Martin Hemler, Dana-Farber Institute, Boston, MA and Coulter Corp., Hialeah, FL, respectively. Monoclonal antibody 1B4 directed against $\beta_{2}$ integrins (29) was prepared as described (30).

Chemotaxis assay. Chemotaxis was performed using modified Boyden chambers and a dual-filter system, consisting of $2-\mu \mathrm{m}$ polycarbonate filters (Nuclepore, Pleasanton, CA) overlying $0.45-\mu \mathrm{m}$ cellulose nitrate filters (Millipore Corp., Bedford, MA), as described previously (12). After fixation and staining, the membrane pairs were evaluated by light microscopy, $\times 400$, for the number of cells that migrated through the upper membrane per high power grid (hpg) during a 40min incubation. Each assay was run in triplicate. Positive controls consisted of $\mathrm{FLP}$ at $1 \times 10^{-8} \mathrm{M}$ in the lower compartment; negative controls consisted of media only in the lower compartment. Results are reported as net cells, that is, cell counts corrected for the negative controls.

Adhesion assay. PMN adhesion was assayed in 72-well Terasaki plates (Nunc HLA plates 76511; Thomas Scientific, Swedesboro, NJ) using a modification of the procedure described by Wright et al. (31). Wells were filled with $5 \mu \mathrm{l}$ of PBS alone or $5 \mu \mathrm{l}$ of PBS with one of the following: $2.5 \mu \mathrm{g}$ HSA, $25 \%$ (Armour Pharmaceutical Company, Kankakee, IL); f MLP, $1 \times 10^{-8} \mathrm{M}$; entactin, $2.5 \mu \mathrm{g}$; S-RGD; $1 \times 10^{-7} \mathrm{M}$; or fibrinogen, $2.5 \mu \mathrm{g}$. The plates were incubated for $60 \mathrm{~min}$ at room temperature, washed with cold PBS, put on ice, and used immediately. PMN were suspended at $2 \times 10^{6}$ cells in Dulbecco's PBS containing human serum albumin, $0.5 \mathrm{mg} / \mathrm{ml}, 3 \mathrm{mM}$ glucose and incubated for $15 \mathrm{~min}$ at $37^{\circ} \mathrm{C}$. For studies involving either antibodies or PMN desensitization with entactin, S-RGD, S-RGE, or S-KGD, PMN were incubated for an additional $15 \mathrm{~min}$ at room temperature. $5 \mu \mathrm{l}$ of PMN cell suspension was added to each well after which the plates were incubated for $30 \mathrm{~min}$ on ice and then for $30 \mathrm{~min}$ at $37^{\circ} \mathrm{C}$. The plates were washed by dipping twice in PBS, covering with parafilm, inverting on a plate holder (PN 11065 carrier; Sorvall Instruments Div., Dupont Co., Newton, CT) and spinning at $600 \mathrm{rpm}$ in a refrigerated centrifuge (RT 6000; Sorvall Instruments) for $1.5 \mathrm{~min}$. The liquid in each well was removed by blotting and then glutaraldehyde, $2.5 \%$ ( $\mathrm{vol} / \mathrm{vol}$ ), was added to each well for $30 \mathrm{~min}$. The glutaraldehyde was removed and the wells washed twice with distilled water and left filled with distilled water. The adherent cells in each well were quantified by phase-contrast microscopy. Six wells were assayed for each parameter assessed.

Phagocytosis assay. The effect of entactin-derived peptides on fibrinogen-stimulated phagocytosis was determined by a fluid-phase assay as described $(10,32)$. Sheep erythrocytes $(E)$ were obtained from 
Whittaker Bioproducts (Walkersville, MD). Opsonized E (EIgG) were prepared as described using a 1:500 dilution of rabbit IgG anti-E (Diamedix Corp., Miami, FL). PMN were suspended in HBSS containing $4.2 \mathrm{mM} \mathrm{NaHCO}_{3}, 10 \mathrm{mM}$ Hepes, $1.5 \mathrm{mM} \mathrm{MgCl}_{2}, 1.5 \mathrm{mM} \mathrm{CaCl}_{2}$, and $1 \%$ ovalbumin, $\mathrm{pH}$ 7.4. PMN $\left(1.0 \times 10^{5}\right)$ were incubated with $12.5 \mu \mathrm{g}$ of either entactin peptide, S-RGD, or a control peptide, peptide 32 , in the presence of $5,000 \mathrm{U}$ of catalase for $15 \mathrm{~min}$ at room temperature in a volume of $50 \mu \mathrm{l}$. Without washing, $50 \mu \mathrm{l}$ of either buffer or the indicated concentrations of human fibrinogen (American Diagnostica Inc., Greenwich, CT) diluted in buffer was added and the mixture was incubated with $15 \mu \mathrm{l}$ of $\mathrm{EIgG}\left(5 \times 10^{7} \mathrm{E}\right)$ for $30 \mathrm{~min}$ at $37^{\circ} \mathrm{C}$. The noningested $\mathrm{E}$ were lysed with $0.83 \%$ (wt/ vol) ammonium chloride. Phagocytosis was assessed by light microscopy and quantified as a phagocytic index, the number of EIgG ingested/100 PMN.

\section{Results}

Entactin mediates PMN adhesion and chemotaxis. Entactincoated surfaces promoted a two- to threefold increase in PMN adhesion compared with uncoated surfaces or surfaces coated with HSA (Fig. 1). Entactin from M1536-B3 extracellular matrix was indistinguishible from recombinant entactin (data not shown ). Both recombinant and M1536-B3 entactins also stimulated neutrophil chemotaxis, with a peak response at a concentration of $15 \mathrm{ng} / \mathrm{ml}\left(1 \times 10^{-10} \mathrm{M}\right)$ (Fig. 2). The cell migration to either type of entactin preparation was equivalent to the chemotactic response elicited with the optimal chemotactic concentration of $\mathrm{MLP}, 1 \times 10^{-8} \mathrm{M}$. "Checkerboard analysis" confirmed that PMN migration to entactin was a chemotactic response ( Table I). The directed migration to entactin was specific because preincubation of PMN with excess entactin blocked chemotaxis to entactin but not to f MLP.

Differentiated HL-60 cells show adhesion and chemotaxis to entactin. Native HL-60 cells did not exhibit adhesion or chemotaxis to entactin or fMLP, however, after incubation with DMSO for $72 \mathrm{~h}$, they did demonstrate adhesion (Table II) to both ligands that was comparable to PMN, and they also responded chemotactically to both ligands. The chemotactic results with $\mathrm{AMLP}$ replicate observations of others (18).

The RGD domain of entactin mediates PMN adhesion and chemotaxis to entactin. Since S-RGD, which consists of RGD and flanking amino acids in entactin, partially blocks attachment of mouse mammary tumor cells to entactin-coated sur-

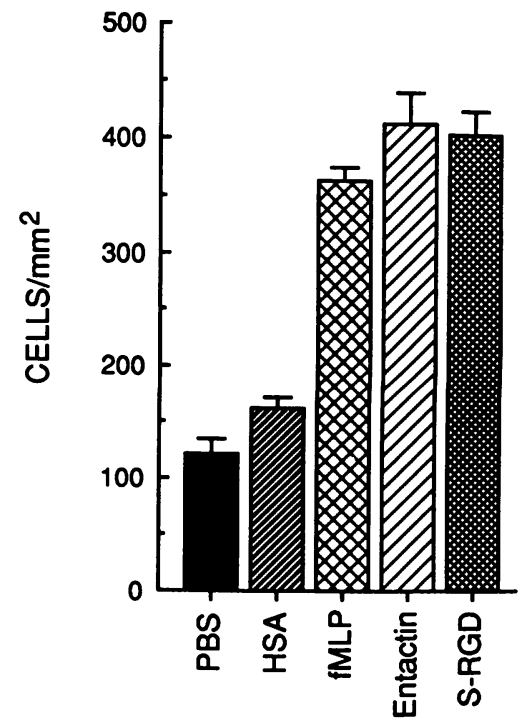

Figure 1. Adhesion of PMN to surfaces coated with PBS; human serum albumin (HSA), $500 \mu \mathrm{g} / \mathrm{ml} ; \mathrm{f} \mathrm{MLP}, 1$ $\times 10^{-8} \mathrm{M}$; recombinant entactin, $500 \mu \mathrm{g} / \mathrm{ml}$; S-RGD, $500 \mu \mathrm{g} / \mathrm{ml}$. See Methods for details of the assay. Data are from a representative experiment and are the mean and SEM of cell counts for six different wells for each condition.

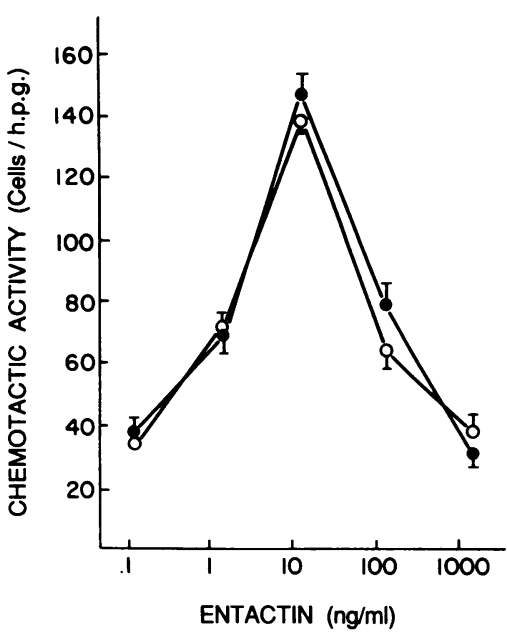

Figure 2. Chemotaxis of $\mathrm{PMN}$ to recombinant entactin $(\bullet)$ and entactin purified from M1536-B3 extracellular matrix (O). The data are from a representative experiment done in triplicate, mean and SEM; $n=15$ at each data point. The positive control, fMLP, 1 $\times 10^{-8} \mathrm{M}$, yielded $144 \pm 5$ cells $/$ hpg. Cell counts are corrected for migration to negative controls, $80 \pm 4$ cells/ hpg.

faces (21), we speculated that the S-RGD domain of entactin might also be involved in PMN responses to entactin. As shown in Fig. 1, PMN demonstrated enhanced adhesion to surfaces coated with S-RGD. This finding suggested that the adhesive properties of entactin for PMN might be mediated by the S-RGD domain of entactin. To test this possibility, and to look specifically at the role of the RGD sequence in S-RGD, PMN were preincubated with S-RGD, S-RGE, or S-KGD and then tested for adhesion to entactin. Controls for these observations were cells preincubated with entactin or S-RGD. As shown in Table III, preincubation with S-RGD blocked adhesion to entactin and S-RGD, but preincubation with either S-KGD or S-RGE had no effect on adhesion to entactin or S-RGD. Importantly, none of the preincubations had any effect upon the adhesiveness of the cells to f MLP.

Similar results were obtained in chemotaxis assays. S-RGD was chemotactic for PMN and preincubation of PMN with S-RGD blocked the chemotactic response to entactin, whereas preincubation with S-RGE had no effect (Fig. 3). At concentrations that reduced chemotactic responsiveness to entactin, however, S-RGD had no effect upon the chemotactic responsiveness of the cells to MLP, indicating that this peptide was not inducing a generalized loss of chemotactic responsiveness.

To further analyze the role of the RGD sequence in entactin in PMN adhesion and chemotaxis to entactin, the RGE-entactin was tested for PMN adhesion and chemotaxis. RGE-entactin did not produce an increase in adhesion over the control, in contrast to the findings described above with entactin purified from M1536-B3 extracellular matrix or recombinant entactin shown in Fig. 1. Similarly, unlike entactin with the RGD sequence, RGE-entactin was not chemotactic (Fig. 4).

Table I. Checkerboard Analysis of the Neutrophil Chemotactic Activity of Entactin

\begin{tabular}{ccrcc}
\hline & \multicolumn{4}{c}{ Entactin, upper compartment } \\
\cline { 2 - 5 } $\begin{array}{c}\text { Entactin, lower } \\
\text { compartment }\end{array}$ & \multicolumn{1}{c}{0} & $10^{-12} \mathrm{M}$ & $10^{-11} \mathrm{M}$ & $10^{-10} \mathrm{M}$ \\
\hline $10^{-12} \mathrm{M}$ & $27 \pm 4^{*}$ & $6 \pm 4$ & $7 \pm 5$ & $6 \pm 4$ \\
$10^{-11} \mathrm{M}$ & $82 \pm 5$ & $51 \pm 5$ & $9 \pm 3$ & $2 \pm 3$ \\
$10^{-10} \mathrm{M}$ & $166 \pm 4$ & $137 \pm 6$ & $30 \pm 3$ & $2 \pm 1$
\end{tabular}

${ }^{*}$ Net cells/hpg \pm SEM, $n=15 ;$ fMLP, $1 \times 10^{-8} \mathrm{M}$, net cells $=153 \pm 6$. 
Table II. Adhesion of $H L-60$ Cells before and after 72- $h$ Exposure to DMSO, $1.3 \%$ ( $\mathrm{vol} / \mathrm{vol})$

\begin{tabular}{lcc}
\hline & \multicolumn{2}{c}{ Adherent cells* } \\
\cline { 2 - 3 } \multicolumn{1}{c}{ Surface coating } & Before & After \\
& DMSO & DMSO \\
\hline & & cells $/ \mathrm{mm}^{2}$ \\
PBS & $21 \pm 4$ & $81 \pm 9$ \\
HSA, $500 \mu \mathrm{g} / \mathrm{ml}$ & $5 \pm 2$ & $75 \pm 4$ \\
S-RGD, $500 \mu \mathrm{g} / \mathrm{ml}$ & $32 \pm 8$ & $239 \pm 11$ \\
Entactin, $500 \mu \mathrm{g} / \mathrm{ml}$ & ND & $217 \pm 12$ \\
\hline
\end{tabular}

* Mean \pm SEM of two experiments, $n=12$ for each condition.

From the results of the adhesion and chemotaxis assays, we conclude that the RGD-containing domain of entactin has a major role in entactin-mediated PMN adhesion and chemotaxis.

Entactin-mediated PMN adhesion and chemotaxis are independent of the integrin $\beta_{1}$ and $\beta_{2}$ families. Because the adhesive interaction between entactin and PMN was dependent on the RGD domain of entactin, we reasoned that a member(s) of the integrin family of adhesive receptors was responsible (33-35). To examine this possibility, we investigated the ability of monoclonal antibodies against $\beta_{1}$ integrins to inhibit entactin-mediated adhesion and chemotaxis. Incubation of PMN with two different monoclonal antibodies to the beta subunit of the integrin $\beta_{1}$ family (A1A5 and 4B4) showed no effect upon the capacity of entactin to mediate PMN adhesion and chemotaxis, although these antibodies blocked laminin-stimulated phagocytosis of EIgG, confirming their potency. Similarly, these antibodies did not affect the capacity of S-RGD to mediate adhesion and chemotaxis.

We used two approaches to investigate whether the $\beta_{2}$ family of integrins is involved in PMN adhesion and chemotaxis to entactin. First, we examined PMN from an individual with complete $\mathrm{LAD}$, a condition in which there is deficient production or maturation of the $\beta$ chain of $\beta_{2}$ integrins (36). As shown in Table IV, LAD PMN adhered to entactin-coated surfaces like normal PMN, although, as expected, they did not adhere

Table III. Effects of Preincubation with Entactin or Entactinrelated Peptides upon PMN Adhesion

\begin{tabular}{lcccll}
\hline & \multicolumn{5}{c}{ Surface coating } \\
\cline { 2 - 6 } Preincubation & PBS & HSA & \multicolumn{1}{c}{ fMLP } & Entactin & S-RGD \\
\hline & & \multicolumn{5}{c}{ cells $/ \mathrm{mm}^{2}$} \\
None & $99(8)^{*}$ & $97(6)$ & $255(15)$ & $236(20)$ & $280(22)$ \\
Entactin & $125(7)$ & $99(7)$ & $224(12)$ & $125(9)$ & $128(8)$ \\
S-RGD & $116(7)$ & $113(9)$ & $239(7)$ & $125(9)$ & $137(9)$ \\
S-KGD & $163(10)$ & $140(7)$ & $267(13)$ & $268(20)$ & $260(15)$ \\
S-RGE & $128(11)$ & $142(7)$ & $265(16)$ & $250(15)$ & $274(17)$ \\
& & & & & \\
\hline
\end{tabular}

* SEM is indicated in parenthesis. PMN were preincubated for 30 min at room temperature with entactin, $1 \times 10^{-8} \mathrm{M}$, or $1 \times 10^{-7} \mathrm{M}$ of one of the following peptides: S-RGD, S-KGD, S-RGE. The adhesive surfaces were prepared with $500 \mu \mathrm{g} / \mathrm{ml}$ of HSA, entactin, or $\mathrm{S}-\mathrm{RGD}$, or $1 \times 10^{-8} \mathrm{M}$ fMLP. Data are the mean and SEM of cell counts for two separate experiments with six wells counted for each condition in each experiment.

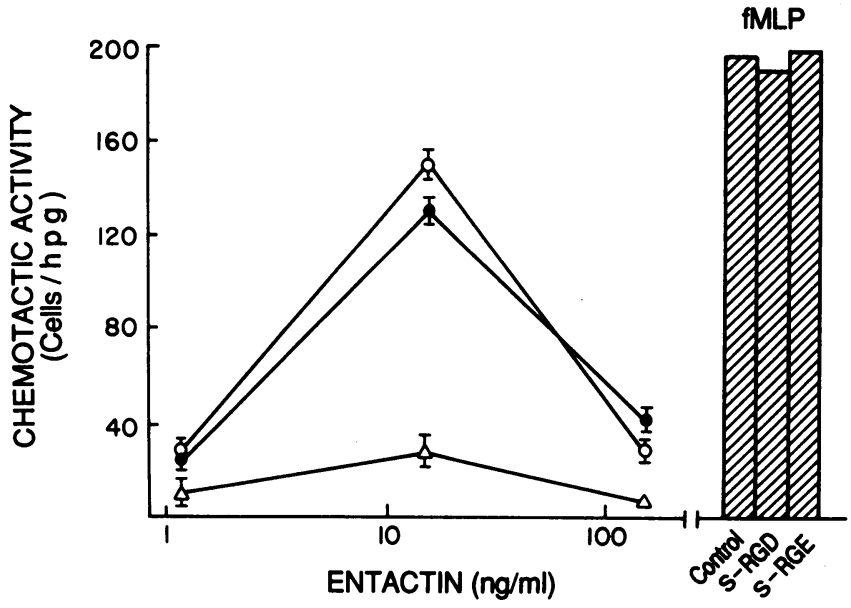

Figure 3. The effect of preincubation of PMN with RGD-containing peptides upon the PMN chemotactic response to recombinant entactin. PMN were incubated with $1 \times 10^{-7} \mathrm{M}$ peptide $(\triangle, \mathrm{S}-\mathrm{RGD} ; \bullet$, $\mathrm{S}-\mathrm{RGE}$ ) or medium only (O) for $15 \mathrm{~min}$ at room temperature, washed, and tested for chemotactic activity to entactin or fMLP. Control cells showed a response of $194 \pm 8$ cells $/ \mathrm{hpg}$ to $1 \times 10^{-8} \mathrm{M}$ f MLP. Cells preincubated with S-RGD or S-RGE showed the same migratory responses to $1 \times 10^{-8} \mathrm{M} \mathrm{fMLP}$ as control cells. The data are from a representative experiment done in triplicate, mean and SEM; $n=15$ at each data point. Cell counts are corrected for migration to negative controls, $81 \pm 3$ cells $/$ hpg.

to fibrinogen-coated surfaces since this event requires $\beta_{2}$ integrins (29). Second, we examined the effect of the monoclonal antibody 1B4 on adhesion and chemotaxis to entactin and found that it had no effect.

The LRI and the IAP mediate PMN adhesion and chemotaxis to entactin. Recently, a novel integrin has been shown to mediate RGD-stimulated phagocytosis (10). This integrin, designated LRI, has not been assigned to an integrin family, but a monoclonal antibody to the beta chain of $\beta_{3}$ integrins (7G2) inhibits the ability of LRI to amplify the phagocytic activity of RGD-stimulated PMN. We observed that 7G2 inhibited PMN adhesion (Fig. 5) and chemotaxis to entactin with minimal effect upon reducing PMN adhesion to $\mathrm{MLP}$. An isotype control antibody had no effect on adhesion or chemotaxis to entactin. To further examine the possible role of LRI in mediating entactin responses, we took advantage of the fact that LRI recognizes the RGD sequence within numerous proteins, includ-

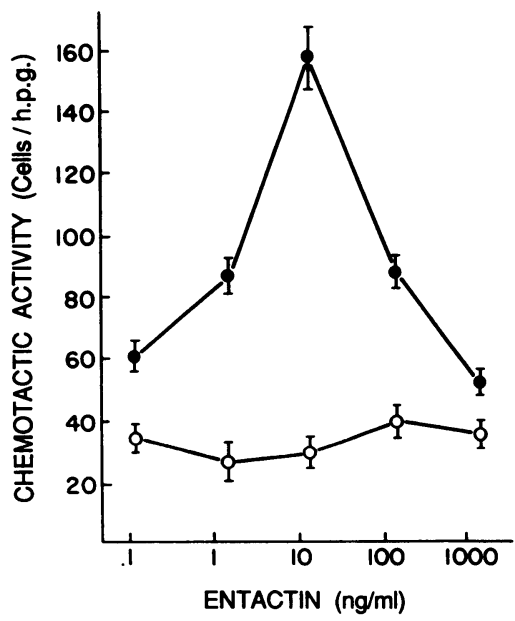

Figure 4. Comparison of the chemotactic activity of entactin (•) and RGE-entactin (O). The data are from a representative experiment done in triplicate, mean and SEM; $n=15$ at each data point. The positive control, f MLP, $1 \times 10^{-8} \mathrm{M}$, yielded $175 \pm 5$ cells/hpg. Cell counts are corrected for migration to negative controls, $89 \pm 4$ cells/ hpg. 
Table IV. Adhesion of LAD PMN and Control PMN to Entactin- and S-RGD-coated Surfaces and the Effect of $B 6 H 12$

\begin{tabular}{lcccc}
\hline \multirow{4}{*}{$\begin{array}{l}\text { Surface } \\
\text { coating }\end{array}$} & LAD & LAD + B6H12 & Control & Control + B6H12 \\
\cline { 2 - 5 } & \multicolumn{5}{c}{ cells/mm ${ }^{2}$} \\
& \multicolumn{5}{c}{ Adherent cells } \\
PBS & $59 \pm 6$ & $68 \pm 5$ & $79 \pm 5$ & $93 \pm 8$ \\
HSA & $58 \pm 8$ & $57 \pm 6$ & $99 \pm 5$ & $96 \pm 6$ \\
Fibrinogen & $13 \pm 2$ & $8 \pm 1$ & $286 \pm 17$ & $132 \pm 9$ \\
Entactin & $181 \pm 12$ & $71 \pm 7$ & $281 \pm 15$ & $99 \pm 5$ \\
S-RGD & $156 \pm 17$ & $65 \pm 7$ & $229 \pm 8$ & $85 \pm 10$ \\
& & & &
\end{tabular}

Results are mean $\pm \mathrm{SEM}, n=6$. $^{*}$ Cells were preincubated with $\mathrm{B} 6 \mathrm{H} 12,10 \mu \mathrm{g} / \mathrm{ml}$, for $15 \mathrm{~min}$ at room temperature.

ing fibrinogen, and that fibrinogen enhances PMN phagocytosis. Fibrinogen-stimulated ingestion is a well-established assay of LRI function (10). Accordingly, we examined the ability of S-RGD to inhibit fibrinogen-stimulated phagocytosis of EIgG. As shown in Fig. 6, preincubation of PMN with S-RGD, but not with a control peptide, inhibited fibrinogen-stimulated ingestion.

Recently, a 50-kD plasma membrane molecule with the capacity to block RGD-stimulated phagocytosis has been identified on a wide variety of cell types (22). This protein has been labeled IAP. Phagocytosis stimulated by RGD peptides, fibrinogen, and other RGD-containing ligands can be blocked by antibody to IAP and by antibody to $\beta_{3}$ integrins, suggesting that the function of IAP is coordinated with $\beta_{3}$ integrins. We found that $\mathrm{B} 6 \mathrm{H} 12$, an anti-IAP monoclonal antibody, inhibited PMN adhesion and chemotaxis mediated by entactin (Fig. 7) without reducing PMN adhesion and chemotaxis to fMLP. We also observed that $\mathrm{B} 6 \mathrm{H} 12$ abolished the adhesion of LAD PMN to entactin and S-RGD (Table IV).

These data with 7G2 and $\mathrm{B} 6 \mathrm{H} 12$, together with the finding that S-RGD inhibits fibrinogen-stimulated phagocytosis, strongly suggest that LRI and IAP have a role in mediating

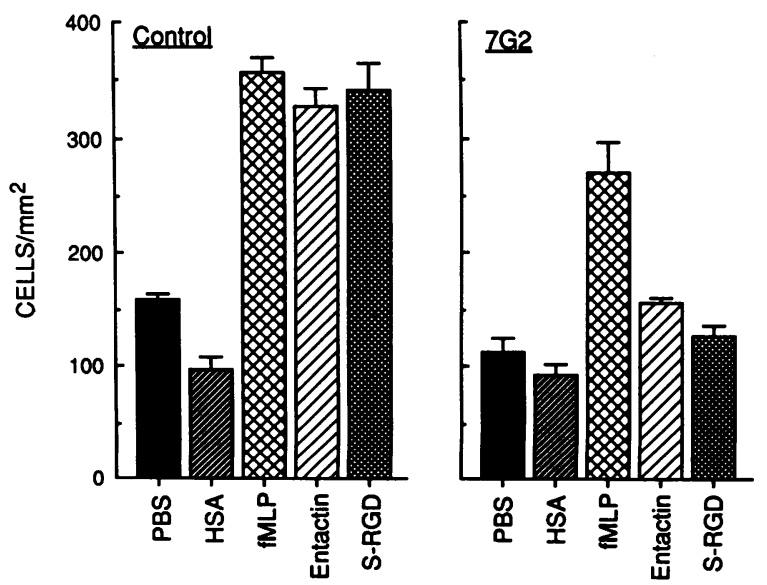

Figure 5. The effect of incubation with $7 \mathrm{G} 2,10 \mu \mathrm{g} / \mathrm{ml}$, upon the adhesive response of PMN to recombinant entactin. The antibody was incubated with the cells for $15 \mathrm{~min}$ at $37^{\circ} \mathrm{C}$ and then the mixture of cells and antibody was used in the adhesion assay. Data are from a representative experiment and are the mean and SEM of cell counts for six different wells for each condition.
Figure 6. The effect of S-RGD on

fibrinogen-stimulated ingestion of EIgG. PMN $\left(1.0 \times 10^{5}\right)$ were incubated with $12.5 \mu \mathrm{g}$ of either S-RGD (O) or an irrelevant control peptide $(\bullet)$ for 15 min at room temperature. Additional buffer or the indicated concentrations of fibrinogen were added and the mixture was incubated with EIgG for $30 \mathrm{~min}$ at $37^{\circ} \mathrm{C}$. Ingestion was assessed by light microscopy as a phagocytic index, the number of EIgG ingested/100 PMN.

signal transduction for PMN adhesion and chemotaxis to entactin.

\section{Discussion}

Basement membranes are complex structures composed principally of type IV collagen, laminin, entactin, and heparan sulfate proteoglycans. Current concepts of basement membrane composition and structure have been presented in several recent reviews $(37,38)$. Previously, two basement membrane components, laminin and type IV collagen, have been shown to display specific interactions with $\operatorname{PMN}(8,9,11-14)$. In the present studies we observed that entactin, an integral $150-\mathrm{kD}$ sulfated glycoprotein basement membrane component that binds to type IV collagen and laminin and to several cell types (15-17), promotes PMN adhesion in the absence of exogenous PMN stimulation and has potent chemotactic activity for PMN at subnanomolar concentrations. The use of recombinant entactin was an important feature of the present studies because it excluded the possibility that the results might reflect the effects of contaminating laminin or type IV collagen.

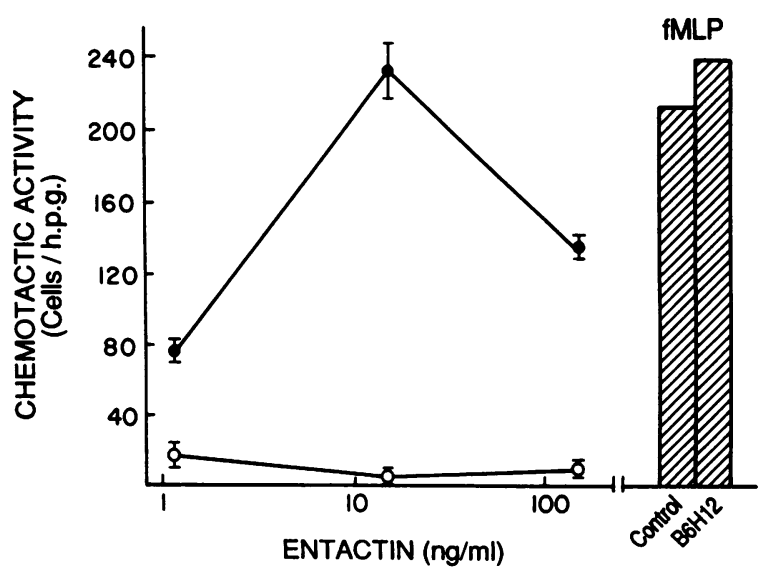

Figure 7. The effect of incubation with $\mathrm{B} 6 \mathrm{H} 12,3 \mu \mathrm{g} / \mathrm{ml}$, upon the chemotactic response of PMN to recombinant entactin. Antibody or media only was incubated with the cells for $15 \mathrm{~min}$ at room temperature and then the mixture of cells and antibody or cells and media only was loaded into the upper compartment of the chemotaxis chambers. (O) with antibody; ( $\bullet$ ) media only. Chemotaxis to $10^{-8}$ $\mathrm{M} \mathrm{fMLP}$ was $220 \pm 4$ cells/hpg in the control and $230 \pm 9$ cells/hpg in the presence of $\mathrm{B} 6 \mathrm{H} 12$. Cell counts are corrected for migration to negative controls, $50 \pm 2$ cells $/ \mathrm{hpg}$. 
We observed that the adhesive and chemotactic properties of entactin for PMN are associated with the single RGD domain in entactin (23). A synthetic peptide that incorporates RGD and several of the amino acids that flank the RGD sequence present in entactin was able to mediate PMN adhesion and chemotaxis and could block the capacity of entactin to mediate these activities. Substitutions for individual amino acids in the RGD sequence of this peptide, such as RGE and KGD, drastically reduced the peptide's capacity to block the adhesive or chemotactic activity of entactin and therefore point specifically to the RGD sequence as critical. The importance of the RGD sequence in entactin, located at amino acid residues $672-674$, in conferring adhesive and chemotactic activity was thoroughly established by studying RGE-entactin, a mutant entactin having glutamic acid substituted for aspartic acid at residue 674 . Entactin having this single amino acid substitution did not display either adhesive or chemotactic activity for PMN. Accordingly, entactin appears to be a ligand in which recognition is based upon its RGD sequence, like fibronectin, fibrinogen, von Willebrand's factor, and vitronectin. It is noteworthy that the recombinant entactin derived from the baculovirus expression system is not glycosylated (20) so that the adhesive and chemotactic activities can not be attributed to possible lectin-like properties. Because native entactin does have carbohydrate (15), however, and because carbohydrate may significantly influence interactions between extracellular matrix components and cells, as recently observed in studies of laminin (39), for example, we also examined the chemotactic and adhesive properties of entactin isolated from extracellular matrix. This entactin demonstrated the same biological activities of PMN adhesion and chemotaxis that we observed with recombinant entactin, thus excluding the possibility that the effects observed with the recombinant entactin were peculiar to the recombinant molecule.

Since the adhesive and chemotactic activities of entactin were mediated by RGD sequences, we tested whether integrins were involved in transducing these activities (33-35). We found that neither $\beta_{1}$ nor $\beta_{2}$ integrins appear to be receptors for the adhesive and chemotactic responses elicited by entactin because monoclonal antibodies to $\beta_{1}$ and $\beta_{2}$ integrins had no effect upon these entactin-mediated activities, and PMN from an individual with LAD, a condition in which leukocytes do not express $\beta_{2}$ integrins, adhered normally to entactin-coated surfaces. In this respect, entactin somewhat resembles thrombospondin, another component of the extracellular matrix that promotes neutrophil motility (40). PMN adhesion to thrombospondin does not involve $\beta_{2}$ integrins (41).

The observations that neither $\beta_{1}$ nor $\beta_{2}$ integrins are involved in entactin-mediated adhesion and chemotaxis raised the possibility that these events involve LRI, a newly described integrin. LRI is an RGD-dependent integrin that mediates the enhanced IgG-associated phagocytosis by PMN observed when PMN are exposed to fibronectin, fibrinogen, von Willebrand's factor, type IV collagen, and vitronectin (10). Although LRI is not well characterized biochemically, it is immunologically related to $\beta_{3}$ integrins. The signal transduction function of LRI to enhance phagocytosis is dependent on a distinct $50-\mathrm{kD}$ plasma membrane protein known as IAP (21). Three lines of evidence suggest that LRI has a central role in mediating PMN adhesion and chemotaxis in response to entactin. First, $7 \mathrm{G} 2$, an anti- $\beta_{3}$ monoclonal antibody known to inhibit RGD binding to LRI, inhibited PMN adhesion and chemotaxis to entactin. Second, B6H12, an anti-IAP antibody, which also inhibits LRI func- tion (22), was as potent as 7G2 at inhibition of PMN adhesion and chemotaxis to entactin. Finally, S-RGD inhibited fibrinogen-enhanced phagocytosis, a known function of LRI (10). Thus, we postulate that entactin is a ligand for LRI. In addition, the present findings extend the known functions of LRI to include signal transduction for adhesion and chemotaxis, as well as regulation of phagocytosis. It should be stressed, however, that these studies do not exclude the possibility that other PMN responses may be elicited by entactin and that these could be mediated by integrins other than LRI and also by nonintegrin receptors. Recent studies of laminin receptors emphasize the extraordinary diversity of receptors that may be responsible for interactions between cells and a single extracellular matrix component (42).

The adhesive activity of entactin for PMN is expressed by cells that have not been activated. Accordingly, interactions between PMN and entactin could serve as an important early event in the migration of PMN out of the vasculature. In this regard it is intriguing to note that entactin also causes release of a 92-kD metalloproteinase from PMN ( $R$. Senior, unpublished observations). This metalloproteinase is contained in the specific granules of the PMN, a PMN compartment that is readily mobilized by a variety of signals $(43,44)$. Since this proteinase has the capacity to degrade a number of extracellular matrix components, including type IV collagen, elastin, and proteoglycans $(45,46)$, there is the interesting possibility that, in addition to mobilizing PMN, entactin also initiates processes that can lead to degradation of extracellular matrix. However, the situation in vivo in the context of an intact basement membrane may be much more complex since other basement membrane components may suppress neutrophil activation (47).

Interactions between entactin and PMN have not been reported previously, but entactin has been shown to be adhesive for several cell types, including mouse mammary tumor cells, human melanoma cells, 3T3 cells, and osteosarcoma cells (17, 21 ). In those studies, as in the present work with PMN, synthetic peptides incorporating the RGD sequence and several of the flanking amino acids in entactin displayed cell adhesive activity and competed with entactin for adhesion. Thus, PMNs are not the only cell type for which entactin has adhesive activity; however, it remains to be determined whether LRI and IAP are involved in mediating the effects of entactin upon other cell types. Recent studies with human prostate carcinoma cells indicate that for this cell type the integrin $\alpha_{3} \beta_{1}$ is the entactin receptor $(48)$.

Considering its presence in basement membranes, the adhesive and chemotactic properties of entactin may be important in acute inflammation. Moreover, recent studies demonstrating that entactin binds fibronectin (49) and fibrinogen (50) add further support for the possibility that entactin may interact with and thereby influence a variety of molecules known to be involved in inflammation and wound healing.

\section{Acknowledgments}

We thank Dr. Donald C. Anderson for providing the LAD PMN and Ms. Marcia Lewis for assistance in preparation of recombinant entactin.

This work was supported by grants from the National Institutes of Health HL 29594 (R. M. Senior), AI 23790 (H. D. Gresham), GM 38330 and AI 24674 (E. J. Brown), CA 21246 and GM 25690 (A. E. Chung), and The Veterans Administration Research Service (H. D. Gresham). 


\section{References}

1. Abramson, S. L., H. L. Malech, and J. I. Gallin. 1991. Neutrophils. In The Lung: Scientific Foundations. R. G. Crystal, and J. B. West, editors. Raven Press, Ltd., New York. pp. 553-563.

2. Butcher, E. C. 1990. Cellular and molecular mechanisms that direct leukocyte traffic. Am. J. Pathol. 136:3-11.

3. Kishimoto, T. K. 1991. A dynamic model for neutrophil localization to inflammatory sites. J. Natl. Inst. Health Res. 3(Sept.):75-77.

4. Smith, C. W., T. K. Kishimoto, O. Abbass, B. Hughes, R. Rothlein, L. V. McIntire, E. Butcher, and D. C. Anderson. 1991. Chemotactic factors regulate lectin adhesion molecule 1 (LECAM-1)-dependent neutrophil adhesion to cytokine-stimulated endothelial cells in vitro. J. Clin. Invest. 87:609-618.

5. Spertini, O., G. S. Kansas, J. M. Munro, J. D. Griffin, and T. F. Tedder. 1991. Regulation of leukocyte migration by activation of the leukocyte adhesion molecule-1 (LAM01) selectin. Nature (Lond.) 349:691-693.

6. Vedder, N. B., R. K. Winn, C. L. Rice, E. Y. Chi, K.-E. Arfors, and J. M. Harlan. 1988. A monoclonal antibody to the adherence-promoting leukocyte glycoprotein, CD18, reduces organ injury and improves survival from hemorrhagic shock and resusucitation in rabbits. J. Clin. Invest. 81:939-944.

7. Huber, A. R., and S. J. Weiss. 1989. Disruption of the subendothelial basement membrane during neutrophil diapedesis in an in vitro construct of the blood vessel wall. J. Clin. Invest. 83:1122-1136.

8. Bohnsack, J. F., S. K. Akiyama, C. H. Damsky, W. A. Knape, and G. A. Zimmerman. 1990. Human neutrophil adherence to laminin. Evidence for a distinct neutrophil receptor for laminin. J. Exp. Med. 171:1221-1237.

9. Bryant, G., C. N. Rao, M. Brentani, W. Martins, J. D. Lopes, S. E. Martin, L. A. Liotta, and E. Schiffmann. 1987. A role for the laminin receptor in leukocyte chemotaxis. J. Leukocyte Biol. 41:220-227.

10. Gresham, H. D., J. L. Goodwin, P. M. Allen, D. C. Anderson, and E. J. Brown. 1989. A novel member of the integrin receptor family mediates arg-glyasp-stimulated neutrophil phagocytosis. J. Cell Biol. 108:1935-1943.

11. Pike, M. C., M. S. Wicha, P. Yoon, L. Mayo, and L. A. Boxer. 1989. Laminin promotes the oxidative burst in human neutrophils via increased chemoattractant receptor expression. J. Immunol. 142:2004-2011.

12. Senior, R. M., A. Hinek, G. L. Griffin, D. J. Pipoly, E. C. Crouch, and R. P. Mecham. 1989. Neutrophils show chemotaxis to type IV collagen and its 7S domain and contain a $67 \mathrm{kD}$ type IV collagen binding protein with lectin properties. Am. J. Respir. Cell Mol. Biol. 1:479-487.

13. Terranova, V. P., R. DiFlorio, E. S. Hujanen, R. M. Lyall, L. A. Liotta, U. Thorgeirsson, G. P. Siegal, and E. Schiffmann. 1986. Laminin promotes rabbit neutrophil motility and attachment. J. Clin. Invest. 77:1180-1186.

14. Yoon, P. S., L. A. Boxer, L. A. Mayo, A. Y. Yang, and M. S. Wicha. 1987. Human neutrophil laminin receptors: activation-dependent receptor expression. J. Immunol. 138:259-265.

15. Chung, A. E., and M. E. Durkin. 1990. Entactin: structure and function. Am. J. Respir. Cell Mol. Biol. 3:275-282.

16. Fox, J. W., U. Mayer, R. Nischt, M. Aumailley, D. Reinhardt, H. Wiedemann, K. Mann, R. Timpl, T. Krieg, J. Engel, et al. 1991. Recombinant nidogen consists of three globular domains and mediates binding of laminin to collagen type IV. EMBO (Eur. Mol. Biol. Organ.) J. 10:3137-3146.

17. Mann, K., R. Deutzmann, M. Aumailley, R. Timpl, L. Raimondi, Y. Yamada, T. Pan, D. Conway, and M.-L. Chu. 1989. Amino acid sequence of mouse nidogen, a multidomain basement membrane protein with binding activity for laminin, collagen IV and cells. EMBO (Eur. Mol. Biol. Organ.) J. 8:65-72.

18. Collins, S. J., F. W. Ruscetti, R. E. Gallagher, and R. C. Gallo. 1979. Normal functional characteristics of human promyelocytic leukemia cells (HL60) after induction of differentiation by dimethylsulfoxide. J. Exp. Med. 149:969-974.

19. Sham, R. L., C. H. Packman, C. N. Abboud, and M. A. Lichtman. 1991. Signal transduction and the regulation of actin conformation during myeloid maturation: studies in HL60 cells. Blood. 77:363-370.

20. Tsao, T., J.-C. Hsieh, M. E. Durkin, C. Wu, S. Chakravarti, L.-J. Dong, M Lewis, and A. E. Chung. 1990. Characterization of the basement membrane glycoprotein entactin synthesized in a baculovirus expression system. J. Biol. Chem. 265:5188-5191.

21. Chakravarti, S., M. F. Tam, and A. E. Chung. 1990. The basement membrane glycoprotein entactin promotes cell attachment and binds calcium ions. $J$. Biol. Chem. 265:10597-10603.

22. Brown, E., L. Hooper, T. Ho, and H. Gresham. 1990. Integrin-associated protein. A $50-\mathrm{kD}$ plasma membrane antigen physically and functionally associated with integrins. J. Cell Biol. 111:2785-2794.

23. Durkin, M. E., C. Chakravarti, B. B. Bartos, S.-H. Liu, R. L. Friedman, and A. E. Chung. 1988. Amino acid sequence and domain structure of entactin.
Homology with epidermal growth factor precursor and low density lipoprotein receptor. J. Cell Biol. 107:2749-2756.

24. Kunkel, T. A., J. D. Roberts, and R. A. Zakour. 1987. Rapid and efficient site-specific mutagenesis without phenotypic selection. Methods Enzymol. 154:367-369.

25. Kunkel, T. A. 1985. Rapid and efficient site-specific mutagenesis without phenotypic selection. Proc. Natl. Acad. Sci. USA. 82:488-492.

26. McClary, J. A., F. Whitney, and J. Geisseloder. 1989. Efficient site-directed in vitro mutagenesis using phagemid vectors. Biotechniques. 7:282-289.

27. Kunkel, T. A. 1987. Oligonucleotide-directed mutagenesis without phenotypic selection. In Current Protocols in Molecular Biology. F. M. Ausubel, R. Brent, R. E. Kingston, D. D. Moore, J. G. Seidman, J. A. Smith, and K. Struhl, editors. Wiley Interscience, New York. pp. 8.11-8.16

28. Groebe, D. R., A. E. Chung, and C. Ho. 1990. Cationic lipid mediated co-transfection of insect cells. Nucleic Acids Res. 18:4033.

29. Wright, S. D., P. E. Rao, C. Wesley, W. C. Van Voorhis, L. S. Craigmyle, K. Iida, M. A. Talle, E. F. Westberg, G. Goldstein, and S. C. Silverstein. 1983. Identification of the $\mathrm{C} 3 \mathrm{bi}$ receptor of human monocytes and macrophages by using monoclonal antibodies. Proc. Natl. Acad. Sci. USA. 80:5699-5703.

30. Graham, I. L., H. D. Gresham, and E. J. Brown. 1989. An immobile subset of plasma membrane CD1 lb/CD18 (Mac-1) is involved in phagocytosis of targets recognized by multiple receptors. J. Immunol. 142:2352-2358.

31. Wright, S. D., J. I. Weitz, A. J. Huang, S. M. Levin, S. C. Silverstein, and J. D. Loike. 1988. Complement receptor type three (CD11b/CD18) of human polymorphonuclear leukocytes recognizes fibrinogen. Proc. Natl. Acad. Sci. USA. 85:7734-7738.

32. Gresham, H. D., L. T. Clement, J. E. Lehmeyer, J. F. M. Griffin, and J. E. Volanakis. 1986. Stimulation of human neutrophil Fc receptor-mediated phagocytosis by a low molecular weight cytokine. J. Immunol. 137:868-875.

33. Albelda, S. M., and C. A. Buck. 1990. Integrins and other cell adhesion molecules. FASEB (Fed. Am. Soc. Exp. Biol.) J. 4:2868-2880.

34. D'Souza, S. E., M. H. Ginsberg, and E. F. Plow. 1991. Arginyl-glycylaspartic acid (RGD): a cell adhesion motif. Trends Biochem. Sci. 16:246-250.

35. Ruoslahti, E. 1991. Integrins. J. Clin. Invest. 87:1-5.

36. Anderson, D. C., and T. A. Springer. 1987. Leukocyte adhesion deficiency: an inherited defect in the Mac-1, LFA-1, p150,95 glycoproteins. Annu. Rev. Med. 38:175-194.

37. Timpl, R. 1989. Structure and biological activity of basement membrane proteins. Eur. J. Biochem. 180:487-502.

38. Yurchenco, P. D., and J. C. Schittny. 1990. Molecular architecture of basement membranes. FASEB (Fed. Am. Soc. Exp. Biol.) J. 4:1577-1590.

39. Chandrasekaran, S., J. W. Dean III, M. S. Giniger, and M. L. Tanzer. 1991. Laminin carbohydrates are implicated in cell signaling. J. Cell. Biochem. 46:115-124.

40. Mansfield, P. J., L. A. Boxer, and S. J. Suchard. 1990. Thrombospondin stimulates motility of human neutrophils. J. Cell Biol. 111:3077-3086.

41. Suchard, S. J., M. J. Burton, V. M. Dixit, and L. A. Boxer. 1991. Human neutrophil adherence to thrombospondin occurs through a CD11/CD18-independent mechanism. J. Immunol. 146:3945-3952.

42. Mecham, R. P. 1991. Laminin receptors. Annu. Rev. Cell Biol. 7:71-91.

43. Boxer, L. A., and J. E. Smolen. 1988. Neutrophil granule constituents and their release in health and disease. Hematol. Oncol. Clin. North Amer. 2:101-134.

44. Singer, I. I., S. Scott, D. W. Kawka, and D. M. Kazazis. 1989. Adhesomes: specific granules containing receptors for laminin, C3bi/fibrinogen, fibronectin and vitronectin in human polymorphonuclear leukocytes and monocytes. J. Cell Biol. 109:3169-3182.

45. Senior, R. M., G. L. Griffin, C. J. Fliszar, S. D. Shapiro, G. I. Goldberg and H. G. Welgus. 1991. Human 92- and 72-kilodalton type IV collagenases are elastases. J. Biol. Chem. 266:7870-7875.

46. Murphy, G., M. I. Cockett, R. V. Ward, and A. J. P. Docherty. 1991. Matrix metalloproteinase degradation of elastin, type IV collagen and proteoglycan. Biochem. J. 277:277-279.

47. Matzner, Y., I. Vlodavsky, R. I. Michaeli, and A. Eldor. 1990. Selective inhibition of neutrophil activation by the subendothelial extracellular matrix possible role in protection of the vessel wall during diapedesis. Exp. Cell Res. 189:233-240.

48. Jewell, K., V. Gray, M. Rojiani, and S. Dedhar. 1991. The receptor for the basement membrane glycoprotein, entactin, is the integrin $\alpha 3 \beta 1$. J. Cell Biol. 115:130a.

49. Wu, C., J. Reing, and A. E. Chung. 1991. Entactin forms a complex with fibronectin and co-localizes in the extracellular matrix of the embryonal carcinoma-derived 4CQ cell line. Biochem. Biophys. Res. Commun. 178:1219-1225.

50. Wu, C., and A. E. Chung. 1991. Potential role of entactin in hemostasis: specific interaction with fibrinogen $\mathrm{A} \alpha$ and $\mathrm{B} \beta$ chains. J. Biol. Chem. 266:1880218807 